\title{
Health Care from Europe to the United States: A Right or a Privilege? The Need for an Historical Approach
}

\begin{abstract}
Matteo BALloni*
Abstract. This paper discusses the different approaches of health care protection in a comparison between Europe and the United States. After an historical introduction over constitutional documents and social rights' definition, the paper focuses over the establishment of health care services in European systems. The United States did not consider health's protection as a right, until the PPACA (2010) required all Americans to buy health insurance and introduced strict regulations for health insurers. The traditional approach has started to change, even though there has been two necessary Supreme Court's rulings to prevent the new health care reform from being set aside.

The change in the welfare State had raised some interesting questions. What does the right to health care mean today? Is it a right, a fundamental right or a benefit? A possible answer involves synchronic and diachronic comparisons but only an historical research approach seems appropriate to understand the current situation and what might be the future.
\end{abstract}

Keywords: Comparative law, Constitutional law, Welfare State, Social rights, Health Care, Obamacare, Supreme Court of the United States

\section{FOREWORD. SOCIAL RIGHTS: DISCUSSING A HOT TOPIC}

The main purpose of this paper is to offer a comparative analysis on health policies to understand if health care is a right or a privilege and the subjects appointed to serve as funder and provider of health deliveries. It is a useful starting point to examine the legal classification given to the health care phenomenon. Health care belongs to a category of rights that broadly pertains to economic and social security. The legal philosophy makes uses term 'social rights' to refer to essential aspects and needs of human life, even if this expression has frequently been considered as a definition with uncertain boundaries, due to the lack of a univocal legal meaning and possible implications over the democratic structure. ${ }^{1}$ According to Jeff King, social rights are 'an institutional mode for protecting our social human rights and those social citizenship rights that a community may include among its constitutional commitments.' 2 This definition certainly refers to a wide subset of entitlements, as health care, education, housing, retirement benefits or social security, affecting citizens' life and wellbeing. At first sight, this catalogue seems clear and definite but for a long time, many scholars have adopted conflicting positions over the nature of these rights, often considered as programmatic provisions not enforceable before the judges. The matter has brought back to the fore because of the economic crisis that involved many European countries.

* Ph.D. Student in Legal Sciences - Comparative Law, Law Department, University of Florence, Italy. This note was presented in a workshop, which took place at Örebro University (Sweden) on 16 October 2015 under the title "Comparative law and the historical perspective". E-mail: matteo. balloni@unifi.it I am grateful to Vittoria Barsotti for helpful comments on earlier drafts.

${ }^{1}$ Longo (2012) 1.

2 King (2012) 20. 
Today, social rights are used by Administrations to harmonize social inequality and to guarantee a substantial equality and all social rights affect the field of public law, producing a considerable increase of Administrative activities ${ }^{3}$. However, this is the final point of a complex sequence of events. An historical approach will be used to better understand this topic and will also highlight the divergences between Liberal State and Social State.

The Liberal State arose between $18^{\text {th }}$ and $19^{\text {th }}$ centuries with the development of a libertarian bureaucracy in favour of personal freedom. The strongholds of Liberalism are the defense of civil liberties; the conception of the minimal State and the principle of individuals' freedom, amongst various characteristics. ${ }^{4}$ The dominant liberal conception lead to the achievement of civil and political rights, i.e., personal liberty or property rights. These 'negative rights' prohibit the Government 'to interfere with individual behavior'5 and the State only needed to refrain from restricting such rights. Similarly, in Anglo-American systems 'Liberty was the most cherished right possessed... in the eighteenth century. It was both an ideal for the guidance of governors and a standard with which to measure the constitutionality of government.' ${ }^{6}$ This system, in accordance with laissez-faire theories arguing against a 'growing drift to state control and intervention', ${ }^{7}$ did not permit the affirmation of social rights. These rights, requiring from the State to act positively to provide some benefits, were instead considered as an undue interference with the rights of the individual. ${ }^{8}$

The $19^{\text {th }}$ century shaped the differences between American and European legal traditions. The results of the widespread European industrial development raised the debate over the desirable planning of measures and actions to improve the more compelling social conditions.' 'How could the market and the representative, timocratic system be made compatible with the extension of political and social rights?' ${ }^{10}$ Social rights was the answer.

Similar social questions were unknown in the United States, where 'the vastness of the country's resources and its new, open frontiers provided land and opportunities on a scale unknown in the Old Continent." 11 Due to this antique arrangement, the American constitutional history developed around the values of freedom and property, without weighing on the State general responsibilities for the welfare and the control of the economy, until 1929 (see Section III).

The first example (and starting point for many other national experiences) of European social regulations is the German model, founded between 1883 and 1889 from Chancellor Bismarck and based on mandatory insurances related to sickness, work-related injury,

3 Mazziotti di Celso (1964) 802, 804.

4 Bin, Petruzzella and Donati (2014) 7-8.

${ }_{5}$ Pascal (2008) 863, 865.

${ }^{6}$ Reid (1988) 1.

7 Clarke, Cochrane and Smart (1987) 117.

8 Laissez-faire theory developed in the Eighteen century. Industrial entrepreneurs proclaimed the individual freedom against 'aristocratic trade monopolies, patronage and the corrupt use of state power', with the aim of clearing away 'the economic and political blockages that stood in the way of unfettered capitalism in Britain'. For a wide examination, Clarke, Cochrane and Smart (1987) 25.

9 Maciocco (2009).

10 Aliprantis and Papageorgiou (2010) 16.

11 Aliprantis and Papageorgiou (2010) 17. 
pension fund and unemployment. From the early 20th Century, the law started to pay an increasing attention to the new social instances and some statements of social rights appeared for the first time in constitutional documents, like Weimar Constitution ${ }^{12}$ (1919) or (in a worldwide dimension) Mexican Constitution (1917). ${ }^{13}$ However, these provisions were considered as 'non-binding principles' ${ }^{14}$ uniquely aimed to suggest broad objectives to the administration. ${ }^{15}$

That was the birth of the 'Social State', with public structures and bodies dispensing variable 'charitable' services for the neediest bracket of the population. The assistance delivered was so far from the present one because it was considered as a kind of 'concession' or favor (not as a right) coming from the political regimes and directed only to specific classes.

The transition to a 'Positive' State with an overall affirmative responsibility dates back to the second postwar period, thanks to a deep transformation of the State and its agencies. Social rights' ideology gradually grew simultaneously with the welfare state conception. In order to protect people's wellbeing, 'the state became responsible for those who could not look after themselves and needed assistance. ${ }^{16}$ According to Asa Briggs, ${ }^{17}$ the welfare state is:

...a state in which organized power is deliberately used (through politics and administration) in an effort to modify the play of market forces in at least three directions - first by guaranteeing individuals and families a minimum income irrespective of the market value of their work or their property; second, by narrowing the extent of insecurity by enabling individuals and families to meet certain 'social contingencies' (for example, sickness, old age and unemployment) which lead otherwise to individual and family crises; and third, by ensuring that all citizens without distinction of status or class are offered the best standards available in relation to a certain agreed range of social services.

12 The Constitution of Weimar tried to renovate the German system by means of democratic ideals, but the attempt made remained unrealized. It contained a broad catalogue of social rights, including the unusual 'duty of the State to act in the international level in order to secure a minimum of social rights to the workers of the world'. Aliprantis and Papageorgiou (2010) 34.

13 Longo (2012) 4.

14 Contiades and Fotiadou (2012) 660, 663.

15 The 1937 Irish Constitution embraced this approach in the Directive Principles of Social Policy, stating at article 45: The principles of social policy set forth in this Article are intended for the general guidance of the Oireachtas. The application of those principles in the making of laws shall be the care of the Oireachtas exclusively, and shall not be cognisable by any Court under any of the provisions of this Constitution. 1. The State shall strive to promote the welfare of the whole people by securing and protecting as effectively as it may a social order in which justice and charity shall inform all the institutions of the national life. Additionally, the article provides a wide catalogue of social dispositions, including:

- 'the right to an adequate means of livelihood' (paragraph 2, clause I),

- 'The State pledges itself to safeguard with especial care the economic interests of the weaker sections of the community, and, where necessary, to contribute to the support of the infirm, the widow, the orphan, and the aged' (paragraph 4, clause I)

- 'The State shall endeavour to ensure that the strength and health of workers' (paragraph 4, clause II).

16 Nistor (2011) 14.

17 Briggs (2000) 10. 
Today, the public administration has to guarantee freedom and safety, but it must also be engaged in governing social and economic life of citizens. The evolution involved the extension of public administration and the recognition of new rights as instruments to protect disadvantaged groups. Sometimes national Constitutions formalized these duties through the legal provision of social and economic rights e.g., Spain, Italy, Belgium, Greece and Portugal. The Spanish Constitution recognizes Spain 'as a social and democratic State, subject to the rule of law, which advocates freedom, justice, equality and political pluralism as highest values of its legal system. ${ }^{18}$ In the same way, the Italian Constitution regulates family's rights, children' protection, health care, education and so on. All these rights are logically connected with the equality principle, ratified by Article 3, clause II, because the Government must act out achieving an equal chance for every citizen to enjoy these fundamental rights related with the full grow of human personality, safeguarded by Article 2. ${ }^{19}$ Similarly, the Greek Constitution provides that 'the State has the right to claim of all citizens to fulfil the duty of social and national solidarity, ${ }^{20}$ while the Belgian laws and rules are bound by the Constitution to guarantee economic, social and cultural rights, taking into account corresponding obligations and determining the condition to exercise them. However, Portugal, above than any other, makes a special reference to social rights, from employment (Articles 58 and 59) and consumers' rights (Article 60), to social security (Article 63), health (Article 64), housing (Article 65), environment (Article 66), family (Article 67), fatherhood and motherhood (Article 68). In fact, the 1976 Portuguese Constitution 'is very detailed, without falling into the trap of being too specific. It lists all social rights under study, distinguishes between various categories of people who might need, and deserve, material assistance... it suggests a number of ways in which the state can meet its obligations to the needy. ${ }^{, 1}$

At the opposite end, the (previous) German Grundgesetz does not include an explicit guarantee of certain social rights but declares the State as a sozialer Rechtsstaat, standing as guarantor for traditional negative and positives rights and new social rights. The United Kingdom is also rather silent on social rights. Although it does not experience a written Constitution, it was the first European nation to draft an inclusive legislation upon health care protection, ca 1948 .

\section{THE RIGHT TO HEALTH CARE IN EUROPE: A BRIEF HISTORICAL SURVEY}

This section focuses upon national health care systems, trying to draw attention to the different stages of development of health care among different countries. However, to avoid misunderstanding of terminology, need the meaning given to the right to health and to the right to health care needs to be clarified. According to countless authors, the right to health

18 Spanish Constitution, Preliminary Part, Section 1 (2016) at link 1.

19 Mazziotti di Celso (1964) 802, 803.

20 Contiades and Fotiadou (2012) 660, 664.

21 De Burca and De Witte (2005) 18. 
is an inclusive right consisting of an ample 'number of entitlements and underlying determinants of health, such as potable water, adequate sanitation, housing, healthy occupational conditions and healthy environmental conditions.'22 Many international documents as 1946 Constitution of World Health Organization, 1948 Universal Declaration of Human Rights or 1978 Declaration of Alma-Ata fostered this right, embracing the definition of health as: $:^{23}$

a state of complete physical, mental and social wellbeing, and not merely the absence of disease or infirmity, is a fundamental human right and that the attainment of the highest possible level of health is a most important world-wide social goal whose realization requires the action of many other social and economic sectors in addition to the health sector.

However, health care is a segment of the broader framework proper to the right to health and its core content refers to health care systems and services, access 'on a nondiscriminatory basis', primary health care and essential drugs. ${ }^{24}$ There is an overall assumption, within the European legal tradition, that most countries recognize health care protection as a fundamental right, or at least a right, sometimes provided and safeguarded by national constitutional documents, ${ }^{25}$ following the original model of Weimar Constitution. ${ }^{26}$ The Italian Constitution deals extensively with health care, ${ }^{27}$ Article 32 safeguards health not only as a collective interest but also as a fundamental right of the individual. It is the only one entitlement defined as 'fundamental' because it represents a prerequisite for all the remaining constitutional rights. This right indubitably creates

22 San Giorgi (2012) 9.

${ }^{23}$ WHO and UNICEF, Declaration of Alma-Ata, International Conference on Primary Health Care, Alma-Ata, USSR, 6-12 September 1978.

${ }^{24}$ San Giorgi (2012) 19. See also Backman (2012); Office of the United Nations, High Commissioner, for Human Rights; World Health Organization, The Right to Health, Fact Sheet No. 31 (2016) at link 2.

25 The Italian Constitution has been the first, followed by Greece, Portugal and Spain in the Seventies. France instead chose not to include health care as a constitutional right. The only general reference to the 'protection de la santé' lies in the Preamble of 1946 Constitution, quoted by the 1958 Constitution. This formulation, together with others social rights, had been considered as a matter of policy debates but not as binding entitlement. For the first time, the Conseil Constitutionnel, with the decision n. 44/1971 ('Having regard to the Constitution and its preamble') included the Preamble of 1946 Constitution and all social rights therein, in the positive law, as part of the 'bloc de constitutionnalité'. See Decision no. 71-44 DC of 16 July 1971, Conseil Constitutionnel (2016) link 3.

${ }^{26}$ Art. 7.8 Weimar Constitution: The Reich is responsible for legislation in the area of health care. Art. 161 Weimar Constitution: In order to maintain health and the ability to work, in order to protect motherhood and to prevent economic consequences of age, weakness and to protect against the vicissitudes of life the Reich establishes a comprehensive system of insurances, based on the critical contribution of the insured. The Constitution of Weimar (1919) at link 4.

27 Art. 32 Italian Constitution: The Republic safeguards health as a fundamental right of the individual and as a collective interest, and guarantees free medical care to the indigent.

No one may be obliged to undergo any given health treatment except under the provisions of the law. The law cannot under any circumstances violate the limits imposed by respect for the human person. 
'a positive burden for public authorities' 28 and many rulings of the Italian Constitutional Court ${ }^{29}$ underlined the duty of a full and exhaustive health care protection. ${ }^{30}$

Other nations share the same legal framework and many constitutional documents support this trend with similar clauses. For example, the Belgian Constitution protects the right to social security, to health care and to social, medical and legal aid (Article 23) while the Spanish Constitution (Section 43) recognizes the right to health protection in parallel with many duties for the State. The public authorities need to 'organize and watch over public health by means of preventive measures and the necessary benefits and services' and 'shall foster health education, physical education and sports. Likewise, they shall encourage the proper use of leisure time'

The Constitution of Portugal contains one of the most significant and detailed disposition over health care. ${ }^{31}$ Article 64 holds 'that all individuals have a right to health care, and goes on to specify that such a right can be respected through preventive, curative, and rehabilitative care and that the state ought to supervise private medicine. ${ }^{32}$.

The EU dimension must also be considered. Nowadays, European rules gained growing importance in many sectors, from pharmaceutical regulations and mutual

28 Barsotti, Carozza, Cartabia and Simoncini (2016) 129.

${ }_{29}$ In this context, Judgment 103/1977 must be mentioned. This ruling concerned hospital care legislation (Statute 132/1968). For our purpose, one paragraph seems particularly meaningful: The key point of the reform... seems the deeply different position, with respect to the past, of the patient, citizen or foreigner, in need of medical treatment. The patient is no more hosted in the hospital for a philanthropic and charitable care, which has its own historic merits, but which authorized, like a due exchange for regaled therapies, the possible utilization of the ill, alive or dead, as object of scientific and didactic examination. Because of the implementation of the principle of the public supreme interest of health protection, consecrated as a fundamental right of the individual by article 32 of Constitution (Judgments 21/1964 and 149/1969), the patient earns, in the new hospital care conception, the new status of legal user of a public service, having a full and unconditional right. This service is administered to fulfill the mandatory obligation of human and social responsibility. Translation edited by the author. See Judgment 103/1977, Italian Constitutional Court (2016) at link 5.

${ }^{30}$ I diritti fondamentali nella giurisprudenza della Corte costituzionale. Relazione predisposta in occasione dell'incontro della delegazione della Corte costituzionale con il Tribunale costituzionale della Repubblica di Polonia. Varsavia, 30-31 marzo 2006 (2016) at link 6.

31 Article 64, Constitution of the Portuguese Republic: Health 1. Everyone has the right to have his or her health safeguarded and the duty to defend and foster it. 2 . The right to the safeguarding of health shall be met by: a. A national health service available to all and free of charge to the extent that the economic and social conditions of citizens require; $b$. The creation of economic, social and cultural conditions that guarantee the protection of children, the young and the old; the systematic improvement of living and working conditions; the promotion of physical fitness and sports in schools and among the people; the development of health education for the people. 3 . In order to ensure the right to the safeguarding of health, the State has a primary duty: a. To guarantee the access of all citizens, regardless of their economic circumstances, to both preventive and remedial medical care and rehabilitation; $b$. To guarantee a rational and efficient medical and hospital service covering the whole country; c. To direct its programme towards the provision of the costs of medical care and medicines from public funds; d. To regulate and supervise privately funded medical practice, coordinating it with the national health service; e. To regulate and supervise the production, marketing and use of chemical, biological and pharmaceutical products and other methods of treatment and diagnosis. 4. The national health service shall have a decentralised management in which the beneficiaries participate.

32 De Burca and De Witte (2005) 18. 
recognition of professional qualifications to the fulfillment of an internal market through the free movement of persons, goods and capital even though health care policies were jealously shield by the Member States. For the first time, the Charter of Fundamental Rights of the European Union explicitly considers social rights and it develops a common European conception of the right to health care. ${ }^{33}$ The Charter was drafted with the aim of giving to 'the European citizen an enhanced human rights protection. ${ }^{34}$ Article 35 states 'Everyone has the right of access to preventive health care and the right to benefit from medical treatment under the conditions established by national laws and practices. A high level of human health protection shall be ensured in the definition and implementation of all Union policies and activities. ${ }^{35}$ The formulation, deferring to the States' legislation, even if formulated as individual entitlement, sets up a programmatic statement. In a final analysis, its effectiveness will depend on the interpretation endorsed by the Court of Justice of the European Union. ${ }^{36}$ However, this clause strengthens the belief that 'health care is to be taken into account in the definition and implementation of all EU policies and activities. $^{37}$

Overall, although these constitutional declarations serve as starting point 'It would be naïve to think that adopting a bill of constitutional social rights would ensure their protection. ${ }^{38}$ How to give an effective protection to the right to health care? Despite various traditions and theoretical arrangements, a common trend among western legal tradition countries can be identified. In fact, European States historically opted for a strong guarantee of citizens' access to a vast catalogue of health care services, not only limited to life-saving treatments but also including primary care, community and hospital service. The mainstays of that model are universal coverage, access to medical treatment not dependent on individual income and the establishment of a comprehensive health service. However, these goals were reached with different financing procedures, which led to the distinction between social insurance based model (the Bismarckian model) and tax based model (the Beveridgian model).

The first system is now in force in Germany, where Chancellor Bismarck established it in 1883, France and the Netherlands. The German model reflects the federal organization of the State through a marked decentralization of powers. The federal authorities define the institutional model and its guidelines while the Länder possess the residual legislative power and the district institutions hold legal supervision over the local health structures. ${ }^{39}$ With regard to the financing perspective, that system adopts a compulsory health insurance to provide universal access without imposing a public monopoly. Corporation (Krankenkassen) and regional sickness funds, under the state's supervision, ensure the coverage of health burdens while individuals have the duty to join a health plan, with different premiums calculated as a percentage of income and jointly financed by

33 The Charter was proclaimed at Nice in December 2000 but it "merely laid down certain principles and ideals to be aspired to". It finally gained the same constitutional status as the Treaties with the 2009 Treaty of Lisbon. See Aliprantis and Papageorgiou (2010) 45.

34 Krüger (2004) XVIII.

35 Charter of Fundamental Rights of the European Union (2016) at link 7.

36 Michalowski (2004) 291; Tega (2013) 67.

${ }^{37}$ Hancher and Sauter (2012) 305.

38 King (2012) 2.

39 Onetti (1995) 35. 
employers and employees. ${ }^{40}$ The private sector has instead an important role as provider of health care services, even if under the Government's strategic thrust. ${ }^{41}$

The Beveridgian model, even if it pursues the same objectives of universality, opted for the institution of a national health care service, through the nationalization of all existing hospitals, financed by central taxation. These features were achieved for the first time in England ${ }^{42}$ with the National Health Service Act of 1946, as a result of the famous Beveridge Report (1942). Lord William Beveridge is considered the founder of English Welfare State because of his redefinition of Government's role in economic and social security fields. Beveridge hoped for an all-inclusive system of economic security for all citizens suggesting the institution of free health service and old age pensions. The government-run National Health Service came into effect in 1948, guaranteeing to the citizenship a wide spectrum of health services, free at point of service, from hospitals and family practitioners to maternity and child welfare services, home nursing, vaccination, through the local authority health services. ${ }^{43}$

The innovations introduced were immediately considered as the more advanced experience in the field of social services, because of the establishment of a standardized, public and centralized system. The offered services, thanks to its universalistic nature, determined an equality status (with reference to certain rights) for all citizens. ${ }^{44}$

Beveridge Report strongly influenced many European nations, like Italy, where the statute 833/1978 finally founded a national health service (Servizio Sanitario Nazionale), which has considerably increased the range of health constitutional provision, ${ }^{45}$ by means of a range of facilities, services and medical treatments aimed to support and recover citizens' physical and psychic health. ${ }^{46}$ The purpose of this statute was to ensure the health

40 See Onetti (1995) 13; Porter and Guth (2012) 71.

41 Onetti (1995) 95.

42 Previously, the English health care was based on the Elizabethan Act for the Reliefe of the Poore (The Poor Law) and on the National Health Insurance Act of 1911. The first statute, enacted in 1601, granted some relief for unfit for work and elderly people, allowing local parishes to collect taxes for the poor. Therefore, it also imposed the subsistence of numerous conditions to limit the availability of public assistance only to people without no alternative source of aid. The National Health Insurance Act guaranteed instead some kind of health insurance to low - and lower-middleincome workers. See Goodman (1980) 5.

43 Allen (1984) 203.

44 Marrocu (2002) 141, 146.

45 Article 1, statute 833/1978: La Repubblica tutela la salute come fondamentale diritto dell'individuo e interesse della collettività mediante il servizio sanitario nazionale. La tutela della salute fisica e psichica deve avvenire nel rispetto della dignità e della libertà della persona umana. Il servizio sanitario nazionale è costituito dal complesso delle funzioni, delle strutture, dei servizi e delle attività destinati alla promozione, al mantenimento ed al recupero della salute fisica e psichica di tutta la popolazione senza distinzione di condizioni individuali o sociali e secondo modalità che assicurino l'eguaglianza dei cittadini nei confronti del servizio. L'attuazione del servizio sanitario nazionale compete allo Stato, alle regioni e agli enti locali territoriali, garantendo la partecipazione dei cittadini. Nel servizio sanitario nazionale è assicurato il collegamento ed il coordinamento con le attività e con gli interventi di tutti gli altri organi, centri, istituzioni e servizi, che svolgono nel settore sociale attività comunque incidenti sullo stato di salute degli individui e della collettività. Le associazioni di volontariato possono concorrere ai fini istituzionali del servizio sanitario nazionale nei modi e nelle forme stabiliti dalla presente legge.

46 Zanetta (2003) 21. 
of 'the entire population, regardless of social and individual backgrounds. ${ }^{\text {' }}$ (The system is financed through general income taxation, copayments and payroll tax and until 2001, mainly depended on the central government's ample powers. The constitutional reform (3/2001) of the Title V of the Italian Constitution changed this. According to this statute, health care became matter of concurrent competence between the State and the Regions. ${ }^{48}$ The State, standing as uniformity's guarantor, must determine the fundamental principles, leaving the legislative power to the Regions. ${ }^{49}$ The commentators, because of such distinct regional regulations, pointed out the actuality of a phenomenon in some ways similar to a healthcare federalism. ${ }^{50}$

In summary, the European conception throughout its long history, developed a definition of health as legal good to be fulfilled toward everyone. If health care is a right, it should necessarily mean equal access to equivalent medical services. Many constitutional documents, laws enacted by Parliaments and Courts jurisprudence formalized the Government's obligation to ensure (or provide) medical services, with clear responsibilities regarding its production, distribution and funding. Welfare state principles are so entrenched in the European culture, that the legal literature talks about welfare systems 'from the cradle to the grave' to underline all the benefits to be obtained as a right during the whole lifespan.

\section{HEALTH CARE IN THE UNITED STATES}

The United States, on the other hand, did not consider health's protection as a right or a constitutional principle, but rather as a benefit, since healthcare is provided by means of a private profit-making insurance market. An organizational structure similar to European National Health Services never existed.

De Tocqueville firstly spoke about American exceptionalism to underline its uniqueness from other countries; from here on, the United States developed around anti-statism, individualism, populism and egalitarianism. ${ }^{51}$ Following these principles, the individual rights' recognition has precluded an expansive statement of social rights, because an Administration activity has often been felt as an obstacle from the right to be free. In fact, 'In our legal tradition, this view of law is integral to constitutional structure, with its

47 Barsotti, Carozza, Cartabia and Simoncini (2016) 129.

48 Art. 117, III paragraph, Italian Constitution: Sono materie di legislazione concorrente quelle relative a: rapporti internazionali e con l'Unione europea delle Regioni; commercio con l'estero; tutela e sicurezza del lavoro; istruzione, salva l'autonomia delle istituzioni scolastiche e con esclusione della istruzione e della formazione professionale; professioni; ricerca scientifica e tecnologica e sostegno all'innovazione per i settori produttivi; tutela della salute; alimentazione; ordinamento sportivo; protezione civile; governo del territorio; porti e aeroporti civili; grandi reti di trasporto e di navigazione; ordinamento della comunicazione; produzione, trasporto e distribuzione nazionale dell'energia; previdenza complementare e integrativa; coordinamento della finanza pubblica e del sistema tributario; valorizzazione dei beni culturali e ambientali e promozione e organizzazione di attività culturali; casse di risparmio, casse rurali, aziende di credito a carattere regionale; enti di credito fondiario e agrario a carattere regionale. Nelle materie di legislazione concorrente spetta alle Regioni la potestà legislativa, salvo che per la determinazione dei princìpi fondamentali, riservata alla legislazione dello Stato.

49 See Barsotti, Carozza, Cartabia and Simoncini (2016) 129-30, Bin, Petruzzella and Donati (2014) 223.

50 Bin, Petruzzella and Donati (2014) 229.

51 Shafer (1991) 16. 
emphasis on separation of powers, checks and balances, procedural protections, and individual rights. We rely on the Constitution to limit the power of the government to restrain our freedoms and cause harm. ${ }^{52}$

For this motivation, the Constitution does not include welfare rights, frequently considered non-enforceable in the courts. ${ }^{53}$ In 1970, the Supreme Court denied the existence of a 'right to welfare' in the Constitution ${ }^{54}$ because 'the intractable economic, social, and even philosophical problems presented by public welfare assistance programs are not the business of this Court.' 55

In DeShaney v. Winnebago County, ${ }^{56}$ the Supreme Court affirmed:

The Due Process Clause of the Fourteenth Amendment was intended to prevent government 'from abusing [its] power, or employing it as an instrument of oppression'. Its purpose was to protect the people from the State, not to ensure that the State protected them from each other. The Framers were content to leave the extent of governmental obligation in the latter area to the democratic political processes.

Consistent with these principles, our cases have recognized that the Due Process Clauses generally confer no affirmative right to governmental aid, even where such aid may be necessary to secure life, liberty, or property interests of which the government itself may not deprive the individual.

Although the liberty protected by the Due Process Clause affords protection against unwarranted government interference . . . it does not confer an entitlement to such [governmental aid] as may be necessary to realize all the advantages of that freedom.

As there is no constitutional obligation upon Administration to protect health, American citizens should buy health insurance from private insurers or receive it from their employer as a part of their salary. Without such insurance, people could not have access to medical care unless they pay the whole cost of the requested service. Too many actors and institutions are involved in health care policies: Federal, state and local administrations; health care providers; insurance companies and interest groups ${ }^{57}$ Despite this variety, the market seems to be the unique appropriate location in which individuals clash each other. ${ }^{58}$

Widespread health insurance is offered by employers as fringe benefits and is also known as employer-sponsored program. Many others diversified insurance policies, much expensive, are available for the single citizen's purchase, as the previous fee-for-service system or the managed care model delivered by Health Maintenance Organizations, social securities managing a network of chosen providers. The fragmentation of these services lead to an irrational system, discriminating citizens according to different capability to pay for medical treatments. Moreover, insurance companies might refuse to draft the insurance contract or rescind it one-sidedness, in case of serious or chronic illness upon the petitioner.

History suggests three turning points in how to restrict the obvious discriminations perpetrated by that private system: the New Deal, the Great Society and Obama's Administration.

52 Parmet (1993) 268, 271.

53 Tushnet (2004) 1895.

54 Hershkoff (1999) 1131, 1133.

55 Dandridge v. Williams, 397 U.S. 471, 487 (1970).

56 DeShaney v. Winnebago County Department of Social Services 489 U.S. 189, 196 (1989).

57 Patel and Rushefsky (2006) 3.

58 Balboni (2010) 386-8. 
President Roosevelt's New Deal, even if not directly connected with health care, represents a deep transformation of American politics, shifting 'the institutional locus of U.S. social policymaking from the states to the federal government. ${ }^{59}$ The original project also included a feasibility study upon a compulsory health insurance. However, this possibility was been rejected to placate American Medical Association dissents. A national health care was indeed understood as a 'socialized medicine', conflicting with the public philosophy of classical liberalism, which imposes a limited role for federal administration. ${ }^{60}$ The New Deal programs defined a new interventionist role for the Federal Administration in aid to weakest bracket of population. The new legislation enacted by the Congress involved a better guarantee of civil and political rights as well as social rights and old age pension (Social Security Act); agricultural programs; banking reform laws and work relief programs (National Labor Relations Act). Although the Supreme Court struck down the first 'social laws', Roosevelt's New Deal was imposed upon the American system from 1937, due to the Supreme Court's unexpected judicial acceptance, incentivized by the famous bill 'Court packing plan' that would have allowed President Roosevelt to elect six new Justices immediately. ${ }^{61}$

The second landmark event is the 'Great Society' which refers to Kennedy and Johnson administrations in 1960 s, who were attempting to increase access to health care services. Power was too widely dispersed among too many institutions and actors did not allow the establishment of a universal insurance. Health insurance offered by employers to the employees was already offering sufficient outcomes. The reform efforts focused upon people left unprotected. Medicare and Medicaid, the only two federal programs that still existing nowadays, were passed as amendments to President Roosevelt's Social Security Act of 1935. Medicare, directly managed by Federal Government, provides access to health care facilities for elderly population and people with disabilities. States instead manage Medicaid program for the poor using federal grants from the Government. ${ }^{62}$ However, every State's choice to participate in Medicaid is optional whichavoids establishing any right to medical assistance for low-income people. An American scholar ${ }^{63}$ affirmed:

The principal objective of the Medicare and Medicaid programs was to provide equal access to healthcare for the elderly people and the poor. Both programs dramatically increased access to health care. Medicare helped alleviate substantial financially related barriers to equal access to health care that existed before the program's enactment. It greatly expanded financial access to acute care for the elderly and disabled.

Nevertheless, treatment's gap among poor, middle class and affluent 'became the law of the land' ${ }^{64}$ ensuring the certainty that each social class deserves different types of coverage. What happens to the uninsured citizens who cannot afford insurance's prices but, meanwhile, are not covered by public programs? The incremental approach pursued by Congress and the lack of a national health insurance system had no longer been enough, pointing out unsolved problems, exacerbated by the recent economic crisis. The emergencies of more and more uninsured people and the need to contain rising health care costs

59 Hacker (2002) 206.

60 Patel and Rushefsky (2006) 42.

61 The Supreme Court case law's change stands out from Lochner v. New York decision (1905)

to West Coast Hotel v. Parrish (1937). SeeVarano and Barsotti (2014) 345.

62 The Federation pays from $50 \%$ to $83 \%$ of program's costs supported by the State.

63 Patel and Rushefsky (2006) 44.

${ }^{64}$ Hoffman (2012) 135. 
suggested compelling federal measures, rejected for years by the Congress, due to pressures coming from interest groups and institutions. ${ }^{65}$

Finally President Obama has gone down in history as the third President approving a sweeping health care reform. This was aimed to provide health care services to the 46 million of uninsured citizens. On March 2010, the Congress enacted the Patient Protection and Affordable Care Act. The Act represents the most comprehensive reform in the United States history, even though it does not establish a universal coverage. According to the statute, the individual mandate introduces a mandatory health insurance, requiring every citizen to have a minimum essential health coverage from 2014. Those who do not buy insurance must pay a penalty to the federal agency Internal Revenue Service. The act also contained strict regulations for insurance companies, which will not be able to exclude people from the insurance's purchase because of personal medical conditions (preexisting condition) or to terminate the insurance's contract if the insured gets sick. The evolution is extremely valuable; Obamacare 'seeks to put an end to insurance company rationing by health status and by gender. Such regulations could also be seen as conferring a right to coverage on individuals, no matter their health condition.' 66

Medicaid expansion is another fundamental provision for expanding the program's coverage through an increase of considered poverty threshold. The States will receive new federal funds to protect, under Medicaid, adults with incomes up to $133 \%$ of the federal poverty level. To make health care affordable, the Act also provides a series of combined provisions, instituting extensive subsidies and the new Health Insurance Exchanges to let the citizens be informed upon prices, tax credits and benefits among different plans.

Nevertheless, the Affordable Care Act gave the way to a bitter public debate and the Republican Party asked for its repeal, due to the supposed Congress' lack of power under the Constitution to enact such reform as it felt like a federal takeover of medical care. There have been necessary two Supreme Court's rulings in 2012 and 2015 to prevent the new health care reform from being set aside.

In National Federation of Independent Business v. Sebelius ${ }^{67}$ many plaintiffs challenged the constitutionality of the individual mandate and the Medicaid expansion. Unexpectedly, ${ }^{68}$ Chief Justice Roberts delivered the opinion of the Court. The individual mandate, fundamental prerequisite for the reform's success, is constitutional with the narrow margin of five votes against four. However, it is not a valid exercise of Congress' power under the Commerce Clause because, even adopting a teleological interpretation, this clause presupposes a commercial activity to regulate, while the individual mandate will control a commercial inactivity (the missed purchase of health insurance) producing effects on interstate commerce. ${ }^{69}$ The individual mandate cannot even be considered a proper means for making health care reform effective, according to the Necessary and Proper Clause, because it will involve a substantial and unlimited expansion of federal authority. Nonetheless, the Supreme Court upholds the individual mandate as a valid exercise of Congress' spending and taxing power because it should be construed as imposing a tax on

65 In 1994, Congress failed to enact the Health Security Act proposed by President Clinton. The bill proposed a considerable restructuring of health care system, including universal coverage and subsidies.

${ }^{66}$ Hoffman (2012) 213.

${ }^{67}$ National Federation of Independent Business v. Sebelius, 567 U.S. (2012).

68 Tushnet (2013).

69 Bologna (2012) 4. 
people who do not buy insurance. The Supreme Court held this interpretation a 'fairly possible one...to save a statute from unconstitutionality. ${ }^{70}$

However, Medicaid expansions violates the Spending Clause because the States have no other choices than to accept the Medicaid extension. If a State do not participate in the new expanded Medicaid program, it would lose all existing Medicaid funding. ${ }^{71}$ The threatened sanction is "unduly coercive'; the Congress should lawfully offer new grants to expand Medicaid's availability, but the States must be free to accept them. Following the Supreme Court decision, if a State will not expand Medicaid program, it will not receive only the new grants, without losing those already existing. ${ }^{72}$

King v. Burwell ${ }^{73}$ concerns the creation of Federal Exchanges and the availability of tax credits to purchase the health insurance. Accordingly to a disposition, the statute exempts from health insurance's purchase anyone who would spend more than $8 \%$ of his income. However the federal subsidies allowed to prevent the override of this threshold. Meanwhile, due to an Act's ambiguity, ${ }^{74}$ tax credits seem available only in case of Exchange established by the State. The question is significant because the citizens of States with a Federal Exchange ${ }^{75}$ should not receive any tax credit. Subsequently, the insurance's cost will exceed $8 \%$ and people will not be compelled to buy any insurance. The Supreme Court saves Obama's health reform concluding that the rule 'allows tax credits for insurance purchased on any Exchange created under the Act', ${ }^{76}$ due to an interpretation that takes into account a reading of the statute's words in their context and 'with a view to their place in the overall statutory scheme.' 77 This pronunciation, even if it allowed the safeguard of health insurance's affordability, raised disapproval because the Court 'has no free-floating power to rescue Congress from its drafting errors. ${ }^{.78}$ Scalia, at the end of his dissenting opinion, even calls the statute SCOTUScare to underline the erroneous philosophy pursued by the Court, reminding 'the American people's decision to give Congress all legislative powers enumerated in the Constitution. They made Congress, not this Court, responsible for both making laws and mending them. ${ }^{79}$

\section{CONCLUDING REMARKS}

Is health care a right or a privilege? This question, as more generally social rights' issue, inevitably involves history. This paper, despite the broad spectrum of the topic, has tried to highlight the changing nature of rights and how, throughout the history, rights upgrade and modify its own meaning and application range.

70 Opinion of Roberts, C.J., 32.

71 See Opinion of Roberts, C.J., 45.

72 See Opinion of Roberts, C.J., 55 ss.

73 King v. Burwell, 576 U.S. (2015)

7426 U.S. Code $\S 36 \mathrm{~B}$ - Refundable credit for coverage under a qualified health plan, referring to taxpayers 'which were enrolled in through an Exchange established by the State under 1311 of the Patient Protection and Affordable Care Act'.

75 The Federal Exchange is regulated by Section 1321.

76 Opinion of Roberts, C. J., 21.

77 Opinion of Roberts, C. J., 15.

78 Opinion of Scalia, J., 17.

79 Opinion of Scalia, J., 18. 
Referring to Europe, it has been mentioned the attainment of a right to health care. This cause of reflection is principally built on three key factors: the legal reception of the right to health care by the law (constitutional law or statute law); the growing influence of European legal order over EU countries and the development of comprehensive health systems. Each and all fulfill the public commitment of the State over citizens' rights. Although some Constitutions did not enshrine social rights, almost all parliaments regulated health care services and non-discriminatory procedures to receive medical treatments. Even if every European country deals with the crisis of welfare state, health care services (either public or private) appear to be the necessary condition to guarantee citizens' medical care and protection. Despite many problems, e.g., distributive policies, the effectiveness of these administrative structures still ensure the level of health care will not fall below a minimum standard.

The tormented latest transformations over American welfare would have little meaning if studied in isolation from the traditional American approach, focused on States sovereignty and never-ending promotion of private market. The constitutional system was careful designed to prevent a tyranny of the majority, reserving the powers not delegated to the States. The typical American system looks askance to the European 'socialized medicine'. It has been summarized that the notion of health care as a private phenomenon and its consequences over American policy. Therefore, American health care cannot still be formally considered a right because the Constitution nor the legislative reforms mention health care as a right.

The federal interference over health care area is doubtless and it is making most Americans eligible to receive a wide range of health care services. Obamacare is undeniably bringing historic change, thanks to a clever compromise among the various competitiveness institutions standing every stage of policy development. Past events allow seeing a precedent of Obama's reform in New Deal programs, when the federal Administration, for the first time, played a key role in American social affairs.

The new American public policy does not want to reduce the Government responsibility over social welfare, as many European countries are trying to do, but rather attempts to battle the first cause of citizen's bankruptcy: Hospitals converted into profit machines and high medical costs. ${ }^{80}$ The Government's commitment is extremely demanding and maybe still incomplete but the reform enacted discloses factual signals of convergence towards a more sustainable, fair and less discretional health care system. Will it be enough to come to imagine in short-term a legal statement of health care as a right also in the United States?

\section{LITERATURE}

Aliprantis, N. and Papageorgiou, I., Social Rights. Challenges at European, Regional and International Level (Bruylant 2010).

Allen, D., 'Health Services in England' in MW Raffel (ed), Comparative Health Systems. Descriptive Analyses of Fourteen National Health Systems (PSUP 1984) 197-257.

Backman, G., The Right to Health. Theory and Practice (Studentliteratur 2012).

Balboni, E., 'La fine della grande anomalia: la riforma sanitaria di Obama guarda all'Europa (2010) 2 Quaderni Costituzionali 386-8.

Barsotti, V., Carozza, P., Cartabia, M. and Simoncini, A., Italian System of Constitutional Justice in Global Context (OUP 2016). 
Bin, R., Petruzzella, G. and Donati, D., Lineamenti di diritto pubblico per i servizi sociali (Giappichelli 2014).

Briggs, A., 'The Welfare State in Historical Perspective' in RE Goodin and D Mitchell (eds), The Foundations of the Welfare State (EEP 2000) 3-40.

Clarke, J., Cochrane, A. and Smart C., Ideologies of Welfare: From Dreams to Disillusion (Century Hutchinson 1987).

Contiades, X. and Fotiadou, A., 'Social Rights in the Age of Proportionality: Global Economic Crisis and Constitutional Litigation' (2012) 10:3 I•CON 660-86.

De Burca, G. and De Witte, B., Social Rights in Europe (OUP 2005).

Goodman, J., National Health Care in Great Britain: Lessons for The U.S.A. (The Fisher Institute 1980).

Hacker, J. S., The Divided Welfare State (CUP 2002).

Hancher, L. and Sauter, W., EU Competition and Internal Market Law in the Health Care Sector (OUP 2012).

Hershkoff, H., 'Positive Rights and State Constitutions: the Limits of Federal Rationality Review' (1999) 112 HLR 1131-96.

Hoffman, B., Health Care for Some. Rights and Rationing in the United States since 1930 (UCP 2012).

King, J., Judging Social Rights (CUP 2012).

Krüger, H. C., 'The European Union Charter of Fundamental Rights and the European Convention on Human Rights: An Overview' in S Peers and A Ward (eds), The European Union Charter of Fundamental Rights (Hart Pub 2004) XVII-XXVII.

Longo, E., Le relazioni giuridiche nel sistema dei diritti sociali (CEDAM 2012).

Maciocco, G., Politica, salute e sistemi sanitari. Le riforme dei sistemi sanitari nell'era della globalizzazione (Il pensiero scientifico 2009).

Marrocu, L., 'Il contesto marshalliano: origini e sviluppo del Welfare State britannico' in C Sorba (ed), Cittadinanza. Individui, diritti sociali, collettività nella storia contemporanea. Atti del convegno SISSCO, Padova, 2-3 dicembre 1999 (Ministero per i beni e le attività culturali direzione generale per gli archivi 2002).

Mazziotti di Celso, M., 'Diritti sociali' (1964) 12 Enc. del diritto 802-7.

Michalowski, S. 'Health Care Law' in S Peers and A Ward (eds), The European Union Charter of Fundamental Rights (Hart Pub 2004) 287-308.

Nistor, L., Public Services and the European Union. Healthcare, Health Insurance and Education Services (TMC AP 2011).

Onetti, A., Il Sistema sanitario Tedesco. Struttura, problemi, prospettive di riforma (Fondazione Clinica del lavoro edizioni 1995).

Parmet, W. E., 'Health Care and the Constitution: Public Health and the Role of the State in the Framing Era' (1993) 20 HCLQ 267-335.

Pascal, E., 'Welfare Rights in State Constitutions' (2008) 39 Rutgers L.J. 863-901.

Patel, K. and Rushefsky, M., Health Care Politics and Policy in America (Sharpe 2006).

Porter, M. E. and Guth, C., Redefining German Health Care. Moving to a Value-Based System (Springer 2012).

Reid, J.P., The Concept of Liberty in the Age of the American Revolution (UCP 1988).

San Giorgi, M., The Human Right to Equal Access to Health Care (Antwerp 2012).

Shafer, B. E., Is America Different? A New Look at American Exceptionalism (Clarendon 1991).

Tega, D., 'I diritti sociali nella dimensione multilivello tra tutele giuridiche e crisi economica' in E Cavasino, G Scala and G Verde (eds), I diritti sociali dal riconoscimento alla garanzia. Il ruolo della giurisprudenza (Editoriale Scientifica 2013) 67-99.

Tushnet, M., In the Balance. Laws and Politics on the Roberts Court (W. W. Norton \& Company 2013).

Tushnet, M., 'Social Welfare Rights and the Forms of Judicial Review' (2004) 82/7 TLR 1895-1920.

Varano, V. and Barsotti, V., La tradizione giuridica occidentale. Testo e materiali per un confronto civil law common law ( $5^{\text {th }}$ edn, Giappichelli 2014).

Zanetta, G. P., L'Europa e la salute (FrancoAngeli 2003). 


\section{LINKS}

1. Spanish Constitution (2016) <http://www.congreso.es/portal/page/portal/Congreso/Congreso/ Hist_Normas/Norm/const_espa_texto_ingles_0.pdf > accessed 21 July 2016.

2. Office of the United Nations, High Commissioner, for Human Rights; World Health Organization, The Right to Health, Fact Sheet No. 31 (2016) <http://www.ohchr.org/Documents/Publications/ Factsheet31.pdf $>$ accessed 21 July 2016.

3. Decision no. 71-44 DC of 16 July 1971, Conseil Constitutionnel de la République Française (2016) <http://www.conseil-constitutionnel.fr/conseil-constitutionnel/english/case-law/decision/ decision-no-71-44-dc-of-16-july-1971.135366.html> accessed 21 July 2016.

4. The Constitution of Weimar (1919) <http://www.zum.de/psm/weimar/weimar_vve.php> accessed 21 July 2016.

5. Judgment 103/1977, Italian Constitutional Court (2016) <http://www.giurcost.org/decisioni/1977/ 0103s-77.html> accessed 21 July 2016.

6. I diritti fondamentali nella giurisprudenza della Corte costituzionale. Relazione predisposta in occasione dell'incontro della delegazione della Corte costituzionale con il Tribunale costituzionale della Repubblica di Polonia. Varsavia, 30-31 marzo 2006 (2016) <http://www.cortecostituzionale. it/documenti/convegni_seminari/STU185_principi.pdf $>$ accessed 21 July 2016.

7. Charter of Fundamental Rights of the European Union (2016) $<$ http://eur-lex.europa.eu/legalcontent/EN/TXT/HTML/?uri=CELEX:12012P/TXT\&from=EN> accessed 21 July 2016. 